\title{
The Important Role of Corporate Entrepreneurship, Digital Capabilities, and Readiness to Change in Business Performance: Moderated by the Adoption of Business Model Innovations in the Newspaper Industry in Indonesia
}

\author{
Patricius Cahanar ${ }^{1}$, Mohammad Hamsal ${ }^{2}$ \\ \{p.cahanar@gmail.com ${ }^{1}$, mhamsal@binus.edu ${ }^{2}$ \} \\ Program Pascasarjana Ilmu Manajemen, Faculty of Business and Economics, Universitas Indonesia, \\ Indonesia ${ }^{1}$; Management Department, Binus Business School Doctor of Research in Management, Bina \\ Nusantara University, Indonesia ${ }^{2}$
}

\begin{abstract}
Technology disruption deeply impacts mass media companies. These companies see a decrease in the number of readers, which in turn results in a decrease in both circulation and advertising revenue. Therefore, mass media companies must be able to create business model innovations that can offset the decline in both revenues. This study aims to examine the role of corporate entrepreneurship, digital capabilities, and readiness to change as moderated by business model innovations, leading to improve the business performance. This research will be conducted in mass media companies, especially newspaper companies, in Indonesia using PLS-SEM.
\end{abstract}

Keywords: Corporate Entrepreneurship, Digital Capabilities, Readiness to Change, Business Model Innovation, Firm Performance, Media Industry.

\section{Introduction}

For several years, print media revenue in Indonesia has decreased - both circulation revenue and advertising revenue, with the later being increasingly taken by the major global companies, namely Google and Facebook [1], [2]. Several newspapers, tabloids and magazines have stopped printing and are only publishing in digital form (websites), such as Suara Pembaruan, Jakarta Globe, Bola Daily, and HAI Magazine [3]. According to a 2019 Press Company Union report, the number of daily newspapers in Indonesia has been declining (SPS, 2019). Meanwhile, the number of print circulation has also decreased [4]. Circulation further declines during the current Covid-19 pandemic [5] because many sales outlets in public places such as stations, terminals, bus stops, 
and others are closed or are seeing less visitors in general. In addition to the decreased circulation, advertising revenue has also dropped dramatically during the pandemic [6], [7]. Manufacturers / advertisers are reducing their advertising budgets to keep costs down, as they experience a decline in sales of their own products, due to the closure of shopping centers, markets, decreased purchasing power, among others.

The difficulties faced by the newspaper industry do not only occur in Indonesia. Other countries are also facing similar difficulties, including large countries such as the United States, Britain, Italy, Scandinavia, Flemish countries, China, Switzerland, Finland and Sweden. [8]-[13]. In the course of its survival and trade, print media have played a major role in advancing human knowledge and creativity [9]. However, the internet and digitization are now changing the face of the newspaper industry at an incredible rate. Technology has made e-commerce, social networking, finding and comparing options, and consuming entertainment easier and more powerful. Internet information is now cheap and abundant; when information grows, people become more comfortable and willing to spend even more time using technology [13]-[15].

Examination into the media industry in Indonesia has been carried out by several researchers related to Competitiveness [16], Dynamic Capability [17], [18], and Strategic Agility [19]. The study for this paper has been conducted to measure the impact of corporate entrepreneurship, readiness to change, and digital capabilities on performance moderated by business model innovation in the newspaper industry in Indonesia which is experiencing digital technology disruption. The novelty of this study lies in its examination of four variables, namely business model innovation, corporate entrepreneurship, digital capabilities, in addition to the readiness to change within organizations in the newspaper industry in Indonesia to deal with changes brought by digital technology.

\section{Literature Review}

\subsection{Business Model Innovation}

Changes in a business environment as triggered by the development of internet technology have caused newspaper companies to change their existing business models [10], [11]. After analyzing the many industries facing disruption, Christensen (Christensen, 2006: p 48) pointed that the fundamental challenge of disruptive technology is "a business model problem, not a technology problem." Today, the internet alongside digitization efforts by leading news and information companies have disrupted traditional newspaper business models [21]. Newspaper publishers face obstacles related to the internet, for although the internet has expanded readership, it is also displacing the hereditary income of the media, namely ad sales and subscriptions, which for centuries have subsidized journalism [22], [23]. Changes in business model innovations may influence a company's ability to improve performance [24], [25]. 


\subsection{Corporate Entrepreneurship}

Adaptation to a changing environment and proactive transformation are essential to the success of mass media business [26]. Corporate entrepreneurship (CE) is an important vehicle in the effort to drive innovation, revitalize organizations, and increase productivity; $\mathrm{CE}$ is also a source of new knowledge that enables companies to build its ability to enter new markets and achieve growth [27]. In other studies, CE leads to superior company performance [28]. Several studies have been conducted on the impact of corporate entrepreneurship on media industry performance, particularly in relations to newspaper companies [29], [30]. In the mass media industry, CE facilitates an entity to become the first to change (first mover), thus allowing it to gain advantage [26]. In facing the challenges of the internet and digitization, it has been proven that CE may mediate IT capabilities with innovation in product performance [31], [32].

\subsection{Digital Capabilities}

Digitalization is fundamentally changing the media industry and its operating environment; meanwhile creative development and innovation are ingredients in content production, work processes and business models [33], [34]. One such development is digital transformation, which is defined as "the use of new digital technologies (social media, mobile phones, analytics or embedded devices) to enable key business enhancements such as improving customer experiences, streamlining operations, or creating new business models" [35]. A multiplatform digital strategy will succeed with effective integration between the IT department, the business department and the editorial department, as well as through a willingness to experiment and innovate- these are actually inter-related [36]. Digital Capabilities also affect company performance [37]-[39].

\subsection{Readiness to Change}

Readiness to change helps to prevent possible resistance to change and increase the effectiveness of an entity's efforts and potential to change [40]. Readiness to change may also improve a company performance [41], [42]. Today's organizations (including media organizations) face an increasingly dynamic environment filled with definite, phenomenal, and unexpected changes [41]. Technological innovation changes every step of the journalistic work process. Journalists need new skills [43]-[45]. Meanwhile, the use of experimental products/equipment has become normal. Citizen journalists and bloggers blur the line between professionals (journalists) and "the people previously known as audience / readers" [10], [14], [22]. This ongoing transformation questions the traditional role of journalists and challenges the current status of journalists [46].

\subsection{Business Performance}

The main purpose of strategic management is firm (i.e. company) performance [17], [47], [48]. In the newspaper industry, firm performance is mainly measured through circulation and advertising [49], [50]. Karimi \& Walter (2016a) added that the current firm performance of mass media

companies can come from either within the core business or outside of the core business (the result of business model innovation), such as from advertisements on websites, paid search, etc. 


\section{Hypothesis Development}

Given the drastic changes in technology and consumption patterns of consumer media, mass media companies, especially newspapers, must find a way to improve their performance in order to survive. To deal with these problems, corporate entrepreneurship [21], digital capabilities [38], and readiness to change [51] which are moderated by business model innovation [29] are expected to improve company performance [21]. These factors may help mass media companies to survive and thrive in a dynamic environment. Moreover, the Covid-19 pandemic is currently happening. The hypothesis developed in this study is as follows:

Corporate Entrepreneurship initiatives are utilized or should be indicative for several purposes, such as profitability growth, business creation, proactive behaviors, strategic renewal, innovativeness, international success, and enhanced competitiveness [32], [52]. This research will support the following hypotheses:

H1 Corporate Entrepreneurship has a positive effect on Business Model Innovation

H2 Corporate Entrepreneurship has a positive effect on Digital Capabilities

H3 Corporate Entrepreneurship has a positive effect on Readiness to Change

Organizations are continually faced with the need to change their structures, objectives, processes, and technologies. Further, they must have the ability to make changes to sustain their competitive advantage [53]. Several studies describe readiness to change as the extent to which individuals hold positive views about the need for organizational change as well as the extent to which individuals perceive that change will positively impact them and the organization as a whole [42], [54], [55]. This research will support the following hypotheses:

H4 Readiness to Change has a positive effect on Digital Capabilities

H5 Readiness to Change has a positive effect on Business Model Innovation

The digitalization of the newspaper industry represents a significant challenge for existing companies to engage new technologies and new business model(s) [10], [54]. This research will support the following hypothesis:

H6 Digital Capabilities have a positive effect on Business Model Innovation

Prior studies have examined the linkage between business model innovation and business performance [21], [56]. This research will support the following hypothesis:

H7 Business Model Innovation has a positive effect on Business Performance

Based on the previous hypotheses development, the proposed research model is depicted in Figure 1. 


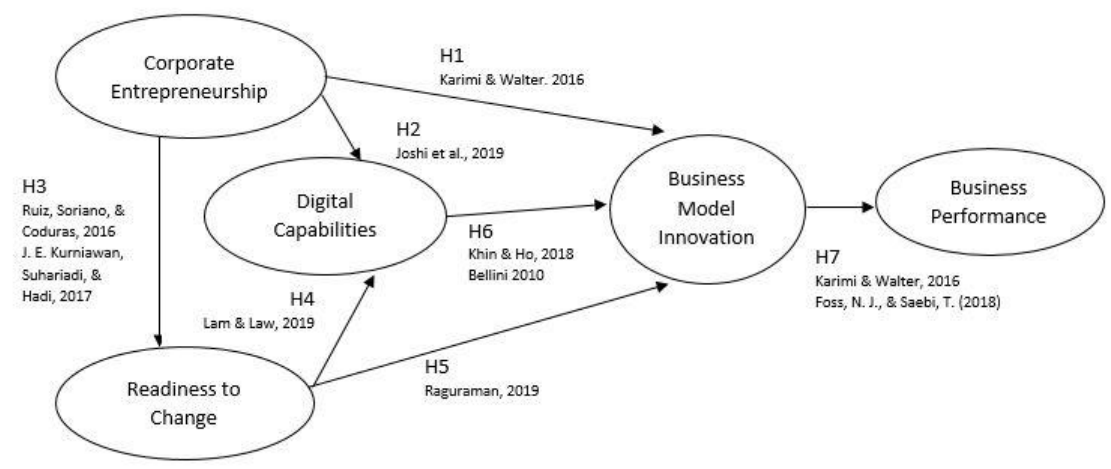

Figure 1. Proposed Research Model

\section{Methodology and Data Analysis}

This research will use quantitative methods where the data to be analyzed are obtained through primary data collection, mainly questionnaires. SEM-PLS will be used as a data processing method, because it can process small sample data efficiently. Recent data (2019) from Serikat Perusahaan Pers (SPS) there are 383 newspaper publishers in Indonesia [4]. To obtain data from the sample, researcher distributed questionnaires to respondents by Google Form, selectively to best represent the answers to the sample. Respondent selection criteria are established to represent answers from work units or directed according to the unit of analysis as defined in this study. The main criteria for selection defined respondents as Chief Editor or Leader of a newspaper business/company based in Indonesia.

\section{References}

[1] A. Wikan, "Berdamai dengan Era Digital," in Media Directory 2019, 2019, hal. 6-7.

[2] T. A. Kristanto, "Media Cetak, Tak Cukup Dua Kaki," J. Dewan Pers, vol. 20, no. November, hal. 9-17, 2019.

[3] M. Sufyan, "Berapa Lama Lagi Usia Koran di Indonesia?,” Kompas.com, 2017. [Daring]. Tersedia pada:

https://nasional.kompas.com/read/2017/07/07/18590671/berapa.lama.lagi.usia.koran.di.indonesia.?p age $=$ all.

[4] SPS, "Rekapitulasi Pertumbuhan Media Cetak Per Wilayah Se-Indonesia," in Media Directory 2019, 2019, hal. 16-18.

[5] Y. Arika, "Kondisi Perusahaan Media Semakin Tertekan," Kompas.id, 2020. [Daring]. Tersedia pada: https://bebas.kompas.id/baca/bebas-akses/2020/07/29/kondisi-perusahaan-media-semakintertekan/.

[6] Y. Arika, "Iklan Turun, Perusahaan Media Berusaha Bertahan,” 2020. [Daring]. Tersedia pada: 
https://www.kompas.id/baca/dikbud/2020/05/13/iklan-menurun-perusahaan-media-berusahabertahan/.

[7] A. Wikan, "Wajah Perusahaan Pers Cetak di Masa Pandemi Covid-19 Pendapatan Turun Drastis, Hingga Merumahkan Karyawan,” SPS Indonesia, 2020. [Daring]. Tersedia pada: https://id.spsindonesia.org/news/dbm1bhic0yt326yk/wajah-perusahaan-pers-cetak-di-masa-pandemicovid-19-pendapatan-turun-drastis-hi.

[8] Y. Arika, "Menggalang Solidaritas, Merawat Jurnalisme," 2020. [Daring]. Tersedia pada: https://www.kompas.id/baca/dikbud/2020/05/26/menggalang-solidaritas-merawat-jurnalisme/.

[9] A. Cawley, "Digital Transitions: The evolving corporate frameworks of legacy newspaper publishers," Journal. Stud., vol. 20, no. 7, hal. 1028-1049, 2019.

[10] A. Cozzolino, G. Verona, dan F. T. Rothaermel, "Unpacking the Disruption Process: New Technology, Business Models, and Incumbent Adaptation,” J. Manag. Stud., vol. 55, no. 7, hal. 1166-1202, 2018.

[11] K. Lehtisaari et al., "Comparing Innovation and Social Media Strategies in Scandinavian and US Newspapers," Digit. Journal., vol. 6, no. 8, hal. 1029-1040, 2018.

[12] B. K. Kim, "Normative uncertainty and middle-status innovation in the US daily newspaper industry," Strateg. Organ., vol. 18, no. 3, hal. 377-406, 2020.

[13] A. Jantunen, A. Tarkiainen, S. Chari, dan P. Oghazi, "Dynamic capabilities, operational changes, and performance outcomes in the media industry," J. Bus. Res., vol. 89, no. June 2017, hal. 251-257, 2018.

[14] J. Karimi dan Z. Walter, "The role of dynamic capabilities in responding to digital disruption: A factor-based study of the newspaper industry," J. Manag. Inf. Syst., vol. 32, no. 1, hal. 39-81, 2015.

[15] L. M. George, "Digital technology, disruption and the market for news," in Handbook on the Economics of the Media, \& R. G. P. dan S. S. Wildman, Ed. Cheltenham: Edward Elgar Publishing, 2016, hal. 259-273.

[16] J. Oetama, "Economic Development, Electronic Media and the Survival of the Newspaper Industry," Media Asia, vol. 24, no. 1, hal. 5-11, 1997.

[17] M. R. Arif, "The Effect of Dynamic Managerial Capabilities in Creating Corporate Entrepreneurship and Firm's Performance: An Evidence from Indonesia Newspaper Industry," 2013.

[18] J. J. N. Prihanto, “TRANSFORMASI DIGITAL MEDIA CETAK DI INDONESIA MEMBANGUN ENGAGED AUDIENCE MELALUI PENDEKATAN DYNAMIC CAPABILITIES,” Binus University, 2016.

[19] E. Agatha, "Pencapaian Kinerja Unit Melalui Strategic Agility yang Dipengaruhi oleh IT Competencies, Entrepreneurial, Alertness, dan Rutin Organisasi pada Industri Media di Indonesia," University of Indonesia, 2019.

[20] C. M. Christensen, "The ongoing process of building a theory of disruption," J. Prod. Innov. Manag., vol. 23, no. 1, hal. 39-55, 2006.

[21] J. Karimi dan Z. Walter, "Corporate Entrepreneurship, Disruptive Business Model Innovation Adoption, and Its Performance: The Case of the Newspaper Industry," Long Range Plann., vol. 49, no. 3, hal. 342-360, 2016.

[22] C. Sparks, H. Wang, Y. Huang, Y. Zhao, N. Lü, dan D. Wang, "The impact of digital media on newspapers: Comparing responses in China and the United States," Glob. Media China, vol. 1, no. 3, hal. 186-207, 2016.

[23] M. Milosevic, "World Press Trends 2016," Wan Ifra, hal. 58, 2016.

[24] N. J. Foss dan T. Saebi, "Business models and business model innovation: Between wicked and paradigmatic problems," Long Range Plann., vol. 51, no. 1, hal. 9-21, 2018.

[25] I. Nugroho, H. Prabowo, F. Alamsjah, dan M. Hamsal, "the Central Role of Business Model Innovation on Firm Performance in," Int. J. Mech. Eng. Technol., vol. 10, no. 03, hal. 457-465, 2019. 
[26] M. Hang, Media Corporate Entrepreneurship - Theories and Cases. Singapore: Springer Science + Business Media, 2016.

[27] S. A. Zahra, "Corporate entrepreneurship as knowledge creation and conversion: the role of entrepreneurial hubs," Small Bus. Econ., vol. 44, no. 4, hal. 727-735, 2015.

[28] M. Bierwerth, C. Schwens, R. Isidor, dan R. Kabst, "Corporate entrepreneurship and performance: A meta-analysis," Small Bus. Econ., vol. 45, no. 2, hal. 255-278, 2015.

[29] J. Karimi dan Z. Walter, "Corporate Entrepreneurship, Disruptive Business Model Innovation Adoption, and Its Performance: The Case of the Newspaper Industry," Long Range Plann., vol. 49, no. 3, hal. 342-360, 2016.

[30] L. Achtenhagen, "Media Entrepreneurship-Taking Stock and Moving Forward," JMM Int. J. Media Manag., vol. 19, no. 1, hal. 1-10, 2017.

[31] M. Yunis, A. Tarhini, dan A. Kassar, "The role of ICT and innovation in enhancing organizational performance: The catalysing effect of corporate entrepreneurship,” J. Bus. Res., vol. 88, no. December 2017, hal. 344-356, 2018.

[32] M. P. Joshi, R. Kathuria, dan S. Das, "Corporate Entrepreneurship in the Digital Era: The Cascading Effect through Operations,” J. Entrep., vol. 28, no. 1, hal. 4-34, 2019.

[33] M. Åkesson, C. Sørensen, dan C. I. Eriksson, "Ambidexterity under digitalization: A tale of two decades of new media at a Swedish newspaper," Scand. J. Manag., vol. 34, no. 3, hal. 276-288, 2018.

[34] C. G. P. Bellini, M. M. Isoni Filho, P. J. De Moura Junior, dan R. D. C. D. F. Pereira, "Self-efficacy and anxiety of digital natives in face of compulsory computer-mediated tasks: A study about digital capabilities and limitations," Comput. Human Behav., vol. 59, hal. 49-57, 2016.

[35] M. Fitzgerald, N. Kruschwitz, D. Bonnet, dan M. Welch, "Embracing Digital Technology: A New Strategic Imperative | Capgemini Consulting Worldwide," MIT Sloan Manag. Rev., vol. 55, no. 1, hal. 1-13, 2013.

[36] G. Doyle, "Re-invention and survival: Newspapers in the era of digital multiplatform delivery," $J$. Media Bus. Stud., vol. 10, no. 4, hal. 1-20, 2013.

[37] K. Z. Zhou dan F. Wu, "Technological capability, strategic flexibility, and product innovation," Strateg. Manag. J., vol. 31, no. 5, hal. 547-561, 2010.

[38] S. Khin dan T. C. F. Ho, "Digital technology, digital capability and organizational performance: A mediating role of digital innovation," Int. J. Innov. Sci., vol. 11, no. 2, hal. 177-195, 2018.

[39] Y. Chen, Y. Wang, S. Nevo, J. Benitez-Amado, dan G. Kou, "IT capabilities and product innovation performance: The roles of corporate entrepreneurship and competitive intensity," Inf. Manag., vol. 52, no. 6, hal. 643-657, 2015.

[40] A. A. Armenakis, S. G. Hariss, dan K. W. Mossholder, "Creating Readiness for Organizational Changes," Hum. Relations, vol. 46, no. 6, hal. 681-703, 1993.

[41] M. D. Haque, A. TitiAmayah, dan L. Liu, "The role of vision in organizational readiness for change and growth," Leadersh. Organ. Dev. J., vol. 37, no. 7, hal. 983-999, 2016.

[42] A. Iqbal dan M. Asrar-ul-Haq, "Establishing relationship between TQM practices and employee performance: The mediating role of change readiness," Int. J. Prod. Econ., vol. 203, no. May, hal. 62-68, 2018.

[43] P. Bakker, "Mr. Gates returns: Curation, community management and other new roles for journalists," Journal. Stud., vol. 15, no. 5, hal. 596-606, 2014.

[44] T. Pierce dan T. Miller, "Basic journalism skills remain important in hiring," Newsp. Res. J., vol. 28, no. 4, hal. 51-61, 2007.

[45] G. Doyle, "Multi-platform media and the miracle of the loaves and fishes," J. Media Bus. Stud., vol. 12, no. 1-2, hal. 49-65, 2015.

[46] S. Grubenmann dan M. Meckel, "Journalists' Professional Identity: A resource to cope with change in the industry?," Journal. Stud., vol. 18, no. 6, hal. 732-748, 2017. 
[47] R. I. Williams, "Measuring family business performance: research trends and suggestions," J. Fam. Bus. Manag., vol. 8, no. 2, hal. 146-168, 2018.

[48] R. Kurniawan, D. Budiastuti, M. Hamsal, dan W. Kosasih, "The impact of balanced agile project management on firm performance: the mediating role of market orientation and strategic agility," Rev. Int. Bus. Strateg., 2020.

[49] A. van Weezel, "Organizational changes in newspaper firms and their relation to performance," JMM Int. J. Media Manag., vol. 11, no. 3-4, hal. 144-152, 2009.

[50] American Press Institute, "Newspaper Next 2.0: Making the Leap Beyond 'Newspaper Companies,"” 2008.

[51] D. T. Holt, A. A. Armenakis, H. S. Feild, dan S. G. Harris, "Readiness for organizational change: The systematic development of a scale," J. Appl. Behav. Sci., vol. 43, no. 2, hal. 232-255, 2007.

[52] R. Martín-Rojas, A. Garrido-Moreno, dan V. J. García-Morales, "Fostering Corporate Entrepreneurship with the use of social media tools," J. Bus. Res., vol. 112, no. November, hal. 396412, 2020.

[53] K. Y. Kwahk dan J. N. Lee, "The role of readiness for change in ERP implementation: Theoretical bases and empirical validation," Inf. Manag., vol. 45, no. 7, hal. 474-481, 2008.

[54] C. Lam dan R. Law, "Readiness of upscale and luxury-branded hotels for digital transformation," Int. J. Hosp. Manag., vol. 79, no. December 2018, hal. 60-69, 2019.

[55] S. Raguraman, "The People-side of Implementing Business Model Innovation: A study on the role of employee motivation, development \& readiness to change in implementing business model innovation," Delft University of Technology, 2019.

[56] H. Guo, J. Tang, Z. Su, dan J. A. Katz, "Opportunity recognition and SME performance: the mediating effect of business model innovation," R D Manag., vol. 47, no. 3, hal. 431-442, 2017. 